\section{LANGUAGE SHIFT AND IDENTITY: EXPLORING FACTORS WHICH CONDITION IDENTITY WHEN A TRADITIONAL LANGUAGE IS LOST ${ }^{1}$}

\section{David M. Eberhard ${ }^{2}$}

บทคัดย่อ

เมื่อภาษาของชนกลุ่มน้อยสูญหายไป อัตลักษณ์ของ กลุ่มอาจสูญหายตามภาษาไปหรือไม่ก็ได้ การศึกษานี้ สำรวจปัจจัยที่เป็นตัวกำหนดการเลือกอัตลักษณ์ของ กลุ่มที่ปรากฎในหมู่ชนกลุ่มน้อย การศึกษานี้เลือก ชุมชนภาษาที่มีปรากฏการณ์การเปลี่ยนภาษาไปถึงขั้น ก้าวหน้ามากแล้วจำนวนหนึ่งเพื่อใช้เป็นกรณีศึกษา ผลที่ได้จากการศึกษากรณีเหล่านี้ คือ กฎเกณฑ์การ เลือกอัตลักษณ์ของชนกลุ่มน้อย ซึ่งแยกเป็นปัจจัย ภายในภาษา และ ปัจจัยแวดล้อมภายนอกภาษา ปัจจัย ทั้งสองประเภทนี้ต่างมีลักษณะเฉพาะตัว วิธีการใหม่ นี้มีข้อดีเหนือคำอธิบายที่เคยมีมาก่อนคือสามารถ บรรยายบอกถึงแรงจูงใจ ในการเลือกอัตลักษณ์กลุ่มแต่ ละแบบ กรอบเกณฑ์การเลือกอัตลักษณ์เหล่านี้จะช่วย ให้นักวิจัยที่ศึกษาเรื่องนี้ในอนาคตทำงานได้ง่ายขึ้น

1 การเปลี่ยนภาษากับอัตลักษณ์ ของกลุ่มชน : การสำรวจปัจจัย กำหนดอัตลักษณ์เมื่อภาษาดั้งเดิมของกลุ่มสูญหาย

2 (เดวิด เอ็ม อีเบอฮาร์ด) Lecturer, Linguistics

Department, Payap University, Chiang Mai, Thailand
เนื่องจากมีแผนที่สำรวจ ตัวเลือกอัตลักษณ์แบบต่างๆ ไว้ให้แล้ว

\begin{abstract}
The loss of a minority group's language may or may not be accompanied by the loss of the same group's identity. This study explores the factors that appear to condition identity choices among minority communities. A number of language communities in advanced stages of language shift are chosen as case studies. Based on these case studies, a framework is proposed that organizes the factors involved in group identity choices into either language internal or language ecology factors, each with their own set of relevant characteristics. The benefit of this new approach over previous explanations is its ability to describe identity choices from a wide array of motivations. Such a framework will facilitate future researchers considering this question, providing them with a roadmap to navigate the various identity options.
\end{abstract}

\section{Introduction}

Language and identity have long been considered two components of human social life that are closely and intrinsically related. Common claims often made in both popular and academic literature attempt to reinforce this connection that is already present in the public imagination. ${ }^{3}$

${ }^{3}$ In the following pages I will borrow from Fishman (1991) who uses the term 'Xish' to refer to anything that is 'of the minority culture', and 'Yish' to signify 'of the majority culture'. Other abbreviations used in this text are: L1 - a mother 
Lose your language, and you'll lose your culture; lose your culture, and you'll lose your identity (Kitingan 1995).

Languages perform a fundamental act of identity for their speakers: you are what you speak (Nettle \& Romaine 2002:22).

In spite of the fundamental nature of language alluded to above, many communities claim to possess an identity that outlasts the language that once supported it. Edwards (2009:205) cites the history of the Jewish people, who switched from ancient Hebrew to Chaldean to Aramaic to Greek to Arabic to Ladino to Yiddish and to Modern Hebrew, while still maintaining their strong sense of Jewish identity. Such examples would suggest that "there is no necessary connection between the continuation of a particular, traditional or ancestral language and the maintenance of feelings of groupness" (Edwards 2009:205). Why this is so will be the focus of this study.

\section{Focusing on minority language communities in shift}

This paper addresses group identity as it is played out within minority language communities who are either undergoing or have already undergone extreme language shift. In such communities, language contact between a majority language (or a language of wider communication,

tongue; L2 - a second language; GIDS - Graded Intergenerational Disruption Scale; and EGIDS Extended Graded Intergenerational Disruption Scale. also known as an LWC) and a minority language has already encouraged a move from bilingualism or multilingualism towards monolingualism (or subtractive bilingualism). As a result of these 'ism' shifts, identity is often at stake or 'up for grabs', and it is in such contexts that the study of group belonging becomes most relevant.

\section{Defining group identity}

Identity has always proven to be a slippery concept. This is due first of all to its subjective nature, meaning that we struggle to know how to measure what we are observing. Secondly, it is complicated by the diverse perspectives on identity that are possible, such as individual vs. group, single vs. multiple vs. hybrid (Tajfel and Turner 1986), innate vs, constructed (Goffman 1959), and the more recent expressions of identity found within the notions of 'imagined communities' (Anderson 1991), 'subjectivities' (Solomon 2005), 'positionings' (Harre and Lagenhove 1999), and 'habitus' (Bourdieu 1977). One can even focus on the difference between enacted and perceived identities, the first as 'my identity for others', and the second, 'the others' identity for me' (Joseph 2004).

In this study, I will be using the term 'identity' in reference to groups and not individuals, recognizing however that these two levels of identity are co-dependent, as the former is obligatorily made up of the latter, and the latter implies participation in the former. The following will be the working definition for 'group identity' used in this study: 
Group Identity: the perception of belonging constructed by members of a particular community through the experience of a shared narrative, together with the internally accepted markers of that belonging which delineate and maintain the boundaries of the ingroup from all out-groups.

This definition owes much to the work of Le Page and Tabouret-Kellers (1985) and their 'acts of identity'. This is the notion that we construct our group identity by a myriad of individual daily acts, such that our acts demonstrate who we are. Any claim of group identity is thus supported by certain acts of identity which are shared by the group, and these can be as varied as language, accent, life-style, occupation, ceremonies, social networks, values, shared heritage, and any other behaviors and or beliefs which distinguish the group. These acts of identity can also be referred to as 'identity markers', of which language is undoubtedly one of the most powerful and versatile. ${ }^{4}$

\section{The Question}

The following question will guide this study: "When minority language communities experience language shift to a dominant language, what are the factors that lead

4 Such identity markers are constrained, however, by context and experience. These constraints are implied in the concept of 'habitus' as outlined in Bourdieu's treatment of personal identity (1977). We cannot choose just any identity markers we please. Our specific narratives limit us. some to continue to self-identify as Xish, while others self-identify as Yish?"

In the following pages, we will look at a number of case scenarios in relation to this question. It will become clear in the process that the loss of Xish language does not always imply the loss of Xish identity. Thus, 4 possibilities will present themselves: 1) Retain Xish identity, 2) Switch to Yish identity, 3) Maintain both Xish and Yish as separate identities (switching between them as needed) 4) Develop a new hybrid $\mathrm{X} / \mathrm{Y}$ identity (possibly alongside a separate Yish identity). To help us investigate the above questions, we will first define what extreme shift means based on a universal scale of vitality. We will then look at case scenarios of numerous languages that represent the various options listed above. Finally, we will attempt to tease out the factors which seem to be contributing to these identity choices.

\section{The EGIDS}

To talk adequately of language shift, some manner of measuring that shift is necessary. Lewis and Simons (2010, 2015a) have recently developed the EGIDS (Expanded Graded Intergenerational Disruption Scale), a vitality scale based on Fishman's GIDS (Fishman 1991), but improving upon it in several ways. ${ }^{5}$ The focus of the EGIDS is to provide a way to assess the vitality of all languages, and in particular to account for

\footnotetext{
${ }^{5}$ Fishman (1991) proposed 8 levels of vitality with the GIDS, improving on the UNESCO LVE scale with only 5 levels (UNESCO, 2011). The EGIDS, on the other hand, is more detailed than either of its predecessors and utilizes 13 motivated levels.
} 
the endangered ones. It also makes explicit the identity + language connection. After having interacted with communities experiencing language shift on 4 continents, I have found the EGIDS to be extremely helpful when assessing languages that are nearer the bottom end of the scale.

With its 13 levels, the EGIDS measures vitality by indexing the level of disruption in intergenerational transmission. Due to the focus of this metric, the levels are scaled with 0 referring to the least amount of disruption, and 10 measuring the most. Thus, the lower numbers correlate to higher levels of language vitality (Lewis, Simons, and Fennig 2015). A chart of the EGIDS is included here with an added column for the more commonly used UNESCO LVE scale. This comparison shows how the EGIDS is more nuanced in its assessment at both extremes of the continuum.

Table 1 the EGIDS

\begin{tabular}{|c|c|c|c|}
\hline \multicolumn{4}{|c|}{ Expanded Graded Intergenerational Disruption Scale } \\
\hline LEVEL & LABEL & EGIDS DESCRIPTION & UNESCO LVE \\
\hline 0 & International & The language is used internationally in many functions. & Safe \\
\hline 1 & National & $\begin{array}{l}\text { The language is used in education, work, mass media, and } \\
\text { government at the nationwide level. }\end{array}$ & Safe \\
\hline 2 & Regional & $\begin{array}{l}\text { The language is used for local and regional mass media and } \\
\text { governmental services. }\end{array}$ & Safe \\
\hline 3 & Trade & $\begin{array}{l}\text { The language is used for local and regional work by both } \\
\text { insiders and outsiders. }\end{array}$ & Safe \\
\hline 4 & Educational & $\begin{array}{l}\text { Literacy in the language is being transmitted through a system } \\
\text { of public education. }\end{array}$ & Safe \\
\hline 5 & Written & $\begin{array}{l}\text { The language is used orally by all generations and used in } \\
\text { written form in parts of the community. }\end{array}$ & Safe \\
\hline $6 \mathrm{a}$ & Vigorous & $\begin{array}{l}\text { The language is used orally by all generations and is being } \\
\text { learned by children as their first language. }\end{array}$ & Safe \\
\hline $6 \mathrm{~b}$ & Threatened & $\begin{array}{l}\text { The language is used orally by all generations but only some } \\
\text { of the child-bearing generation are transmitting it to their } \\
\text { children. }\end{array}$ & Vulnerable \\
\hline 7 & Shifting & $\begin{array}{l}\text { The child-bearing generation knows the language well enough } \\
\text { to use it among themselves but none are transmitting it to their } \\
\text { children }\end{array}$ & Definitely Endangered \\
\hline $8 \mathrm{a}$ & Moribund & $\begin{array}{l}\text { The only remaining active speakers of the language are } \\
\text { members of the grandparent generation. }\end{array}$ & Severely Endangered \\
\hline $8 \mathrm{~b}$ & Nearly Extinct & $\begin{array}{l}\text { The only remaining speakers of the language are members of } \\
\text { the grandparent generation or older who have little opportunity } \\
\text { to use the language. }\end{array}$ & Critically Endangered \\
\hline 9 & Dormant & $\begin{array}{l}\text { The language serves as a reminder of heritage identity for an } \\
\text { ethnic community. No one has more than symbolic } \\
\text { proficiency. }\end{array}$ & Extinct \\
\hline 10 & Extinct & $\begin{array}{l}\text { No one retains a sense of ethnic identity associated with the } \\
\text { language, even for symbolic purposes. }\end{array}$ & Extinct \\
\hline
\end{tabular}

(Source: borrowed from Lewis and Simons 2010:110). 
A unique quality of the EGIDS chart (in relation to other vitality scales) is that it includes a level for 'language-used-only-asidentity-marker', or level 9. This is the final stage in the process of language shift before a language reaches extinction. It represents communities using language solely for its symbolic function of marking their group identity. ${ }^{6}$ At this stage there is no transmission of information in L1. Instead, we observe the usage of short ritual phrases, greetings, names, songs or kinship terms that evoke the traditional identity and tell people who they are. Therefore, the EGIDS allows us to categorize these sorts of languages in a way that other scales do not. It is important to recognize that a level 9 language is still present in the life of a community even when it is being used only for a symbolic function, and even when its speakers have an extremely reduced level of fluency. What is often thought of as a very minimal and temporary form of bilingualism can become a stable sort of bilingualism if the community is willing to establish and pass on to their children the norms regarding the usage of these minimal symbols. These norms can be seen in many cases where fluency is not present but a highly reduced L1 usage (such as the use of greetings, ritual speech, place names, music lyrics) has marked identity for a significant time period, and that usage appears stable. Examples of language communities at Level 9 are the Irish and Welsh in the British Isles (Edwards 2009:251), the Kwak'wala in Canada

6 Edwards (2009:56) also observed that the identity function of language may exist on its own. The "two aspects of language are separable - the communicative and the symbolic - and it is possible for the latter to remain important in the absence of the former".
(Anonby 1999), and the Nusa Laut of Indonesia (Lewis, Simons, and Fennig 2015).

\section{Example communities}

Data regarding the identity claims of endangered language communities is not easy to come by. Due to the inherent difficulties of researching this topic, most authors either avoid identity completely, or only mention it in passing. The data below was gathered from a list of ad-hoc sources, and was not chosen in any principled fashion. There is no claim that the languages listed below are representative of larger linguistic areas or families or cultures. I offer them instead as examples of what the identity of endangered communities might look like.

\section{Language shift with Identity shift}

Table 2 gives 8 examples of language communities that are far along in the language shift process from $\mathrm{X}$ to $\mathrm{Y}$ (or have already shifted), and who have shifted their main identity to a Yish social identity as well.

\section{Language shift without identity shift}

Table 3 provides 12 more examples of language communities that are in the same advanced process of shift to a majority language, but who reportedly have maintained their traditional identity as their main claim of group belonging. 
Table 2 Language shift with identity shift

\begin{tabular}{|c|c|c|c|c|}
\hline Language & Country/region & EGIDS & Language Shift to & Main Identity Claim \\
\hline 1.Torá & Brazil & 10 & Portuguese & $\begin{array}{l}\text { Brazilian } \\
\text { farmers/fishermen } 7\end{array}$ \\
\hline 2.Northern Pame ${ }^{8}$ & Mexico & $8 b$ & Spanish & $\begin{array}{l}\text { Mexican sugar cane } \\
\text { farmers }\end{array}$ \\
\hline 3.Sabanê & Brazil & $8 b$ & Portuguese & Brazilian land settlers \\
\hline 4.Domaaki & Pakistan & $8 \mathrm{a}$ & Burushaski -LWC in north & Pakistani \\
\hline $\begin{array}{l}\text { 5.Tai Lue } \\
\text { (urban) }\end{array}$ & Thailand & 10 & $\begin{array}{l}\text { Kammuang } \\
\text { (Northern Thai) }\end{array}$ & $\begin{array}{l}\text { Northern Thai } \\
\text { (Muang/Lanna) }\end{array}$ \\
\hline 6.Mon & Thailand & 9 & Thai & Thai \\
\hline 7.Marori & Indonesia & $8 \mathrm{~b}$ & Indonesian and Marind & Indonesian \\
\hline 8. Terena & Brazil & 7 & Portuguese & $\begin{array}{l}\text { Terena and Brazilian } \\
\text { hybrid } \\
\text { (the youth) }\end{array}$ \\
\hline
\end{tabular}

Table 3 Language shift without identity shift

\begin{tabular}{|l|l|l|l|l|}
\hline Language & Country/region & EGIDS & Shifting to Language & Main Identity claim \\
\hline 9.Lotud & Malaysia & $8 \mathrm{a}-10$ & Sabah Malay & Lotud \\
\hline 10.Irish & Ireland & $8 \mathrm{a}$ & English & Irish \\
\hline 11.São Tomé & $\begin{array}{l}\text { São Tomé e } \\
\text { Príncipe/Africa }\end{array}$ & 7 & Portuguese & Forro \\
\hline 12.Tlingit & US/Alaska & $8 \mathrm{~b}$ & English & Tlingit \\
\hline $\begin{array}{l}\text { 13.Tai Lue } \\
\text { (rural) }\end{array}$ & Thailand & $8 \mathrm{~b}$ & $\begin{array}{l}\text { Kammuang } \\
\text { (Northern Thai) }\end{array}$ & Tai Lue \\
\hline 14.Fulniô & Brazil & 7 & Portuguese & Fulniô \\
\hline 15.Mon & Myanmar & 10 & Burmese & Mon (nationalist movement) \\
\hline $\begin{array}{l}\text { 16.Batak } \\
\text { (migrant) }\end{array}$ & Indonesia & 7 & Bahasa Indonesian & Batak and Indonesian \\
\hline $\begin{array}{l}\text { 17.Maori (Cook } \\
\text { Island) }\end{array}$ & New Zealand & 7 & English & Cook Island Maori \\
\hline 18. Urimo & Papua New Guinea & 7 & Tok Pisin & Urimo \\
\hline 19. Kajaman & Malaysia, Sarawak & 7 & Sarawak Malay & Kajaman \\
\hline 20. Calon & Brazil (Guapó) & $8 \mathrm{a}$ & Portuguese & Calon \\
\hline
\end{tabular}

(Sources for the above information are provided in the appendix. ${ }^{9}$ )

\footnotetext{
${ }^{7}$ More recently, however, a movement has begun to re-assert their Torá identity (S. Anonby, personal communication, 2015).

${ }^{8}$ This description applies only to the Northern Pame communities that are closest to town. Those that are more rural are at EGIDS level 6a, raise goats and farm corn instead of sugar cane, and have a stronger Pame identity (S. Berthiuame, personal communication, 2015).

${ }^{9} \mathrm{~A}$ portion of the data is a result of my 18 years of researching and interacting with local language communities in west-central Brazil, as well as personal communication with mother-tongue participants of language development workshops I have offered in Brazil, Malaysia (Sabah, Sarawak, and West Malaysia), Papua New Guinea (Sepik and Highlands), and west Africa.
} 


\section{Factors conditioning identity}

The above statistics, although incipient, offer specific examples of the type of diversity found within endangered language communities spanning several continents. The picture they paint is that some groups undergoing language shift are maintaining a variety of Xish identity (Table 2) and others are opting to transition to some variety of Yish identity (Table 3). The question then is why do some shifting communities choose to maintain Xish identity while others do not? What are the factors involved in that choice? We will begin this discussion by identifying two general types of factors that affect identity: 1) those that are characteristic of the language community itself, and 2) those that are related to the broader language ecology.

\section{Language community factors}

Internal influences from within minority language communities can affect identity choices. These can be characterized into two broad categories: Obligatory Identity Markers, and Perceived Benefits of Xish.

\section{Obligatory Identity Markers}

Le Page and Tabouret-Keller's (1985) 'acts of identity' provides an initial base for exploring what constitutes group belonging within individual communities. A number of authors have also taken the 'acts of identity' approach in attempting to understand the self-ascribed identities of minority groups (Schmidt, Starks, et al, Hutton, etc.).

I propose that such acts of identity (or identity markers) are of two types: active identity markers and passive identity markers. This is similar in spirit to Jenkin's (1997) categories of 'objective and subjective characteristics', echoed in Schmidt (2009:4-6), and parallel to Barth's (1969:14) 'overt signals' vs 'value orientations'. Although it may seem counterintuitive to conceive of 'acts' that are passive, this category becomes important for communities who have passed completely through the language shift process. Many such groups have no active markers of Xish identity left. If these communities desire to maintain a sense of belonging with the same Xish group boundaries, they must resort to a set of covert acts, such as remembering a shared heritage, or valuing or believing a shared set of standards or beliefs. These mental processes, then, are the passive markers needed to complement the 'acts of identity' notion. Doing so makes it applicable to a greater number of groups, particularly those who find themselves in an advanced stage of shift. (One of the critiques of the acts of identity approach was the lack of such passive markers - see Keyes 1992, citing Moerman 1965). ${ }^{10}$

The set of possible human behaviors used as symbols of 'who we are' appears to be limited only by the creativity of human

\footnotetext{
${ }^{10}$ Keyes (1992), quoting Moerman, says the Tai Lue see themselves as Lue due to 30 common cultural traits, but 16 of these are not practiced anymore (or only by the very elderly), and 8 are shared with the Yuan, whom they insist are a distinct group. He points out the inconsistencies of self-labeling and of using a list of cultural traits to do so. What was missing was the use of passive markers to allow the Tai Lue to express their identity in terms of shared history, ancestry, etc.
} 
societies and the experiences of their individual members. The list below is a representative set of identity markers found in the literature, sub-divided into an active and a passive set.

Table 4 Examples of active and passive identity markers

\begin{tabular}{|l|}
\hline Typical Active Identity Markers \\
\hline way of life, livelihood, work, dress/food, \\
religion, language, ceremonies, musiclart forms, \\
marriage patterns/restrictions, place of \\
residence - rural/or in Xish area, accent in L2, \\
values, beliefs, social networks, traditional \\
authority, artefacts/material culture. \\
\hline Typical Passive Identity Markers \\
\hline $\begin{array}{l}\text { shared history/ancestry, racelethnicity, mother } \\
\text { or father's ethnicity, clan, land ownership, } \\
\text { physical characteristics, existence of 'some' } \\
\text { speakers, knowledge of Xlanguage existence }\end{array}$ \\
\hline
\end{tabular}

Language appropriately falls into the active set of markers. Many active markers, however, including language, may be employed for either symbolic or functional purposes (and often both). When oral language is used fluently by at least some segment of a community, it fills a functional role of communication. But as language shift progresses, the role of a traditional language can diminish to a point where it is used only in a symbolic fashion, marking identity and performing little else (Lewis and Simons 2015: 104-123; see also the discussion on EGIDS level 9 in section 3). Nevertheless, even a small amount of use is still an 'active' behavior, albeit a very limited one.

Beyond language, many other active markers of Xish identity are possible. It is common for a group in advanced shift to evoke other markers for this purpose and not use language at all. According to Dorian (1999:31), "Because it is only one of an almost infinite variety of potential identity markers, [a language] is easily replaced by others that are just as effective. In this respect the ancestral language is functionally expendable."

Pragmatically speaking, there seems to be a qualitative difference between active and passive markers, the active markers reflecting a stronger identity than the passive ones, since the former affects a greater portion of everyday life. ${ }^{11}$ On the other hand, identities based on active markers may be less salient and less emotive in the minds of the community than those based mostly on passive markers. This has been a common observation in my own research across numerous cultures. This is due to the opposing relationship between what I am calling the Integration scale and the Saliency scale. Integration here is measuring how much a particular marker is integrated as a functional component of everyday life. Saliency measures the awareness individuals have of the language + identity nexus in their own lives (based on Edwards 2009:254). Such awareness (and emotional response) typically grows as the prospects for maintaining a language and/or identity wane. This is why Xish activism is often championed by those who do not speak Xish (or do not speak it fluently).

\footnotetext{
${ }^{11}$ Although passive markers reflect a weaker identity than active ones, that in itself does not make them less valid.
} 


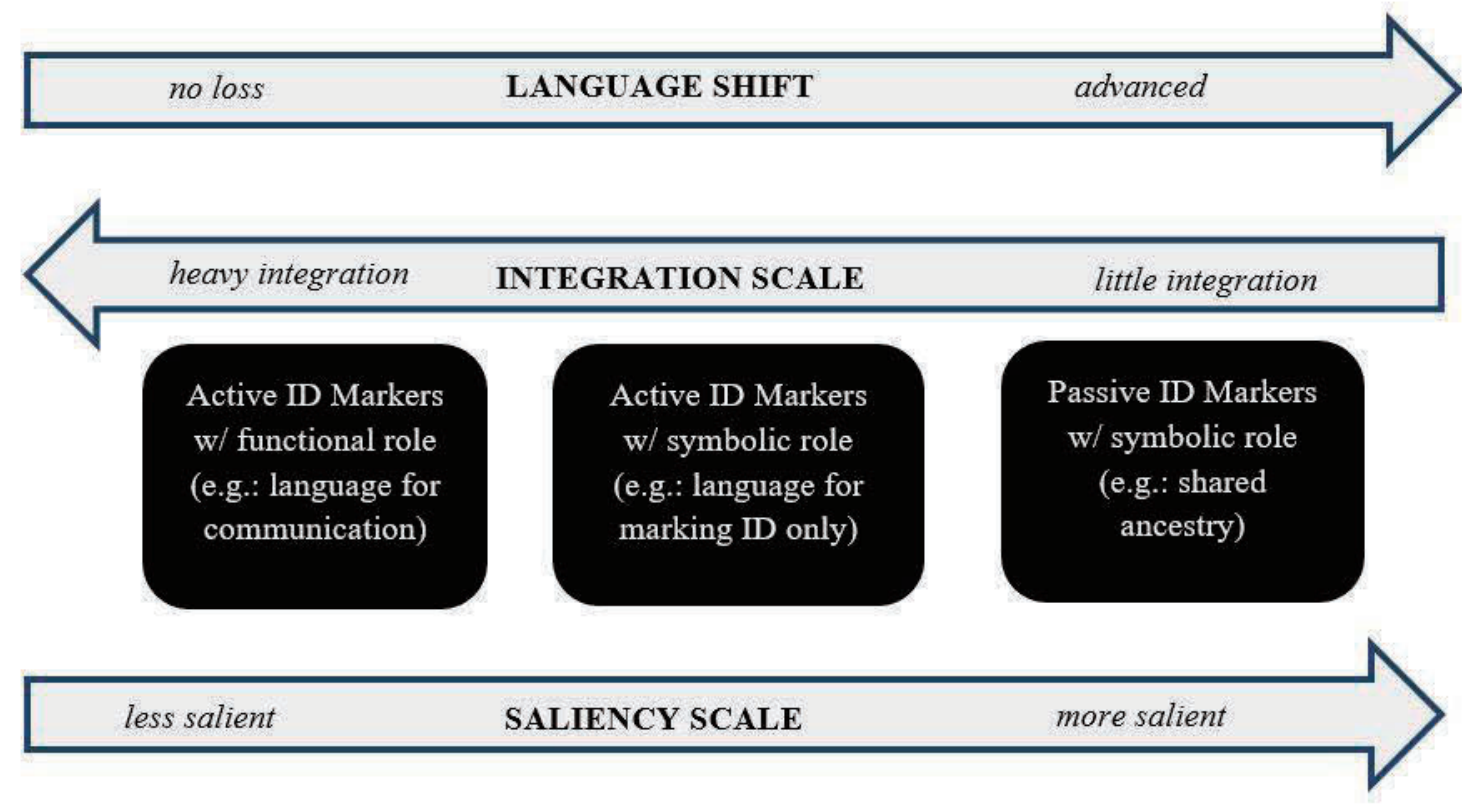

Figure 1 Integration + Shift + Saliency

Among the multitudinous 'acts' of identity, both active and passive, communities often establish norms in regards to which one (or more) of these markers constitutes the final boundary marker of Xish, i.e., the minimal requirement of an Xish identity when all else is gone. When groups have lost most of their traditional world, this is the identifier that still tells them and others who they are, delineating in-groups from out-groups. In Barth's words (1969:38), "Ethnic boundaries are maintained...by a limited set of cultural features". Such boundary markers differ from culture to culture, and may even vary across time within the same culture. I will refer to this special boundary symbol as a community's obligatory identity marker.
According to Simon,

...collective identity arises when self-definition is focused upon a shared self-aspect, which may be inter alia a belief, a symbol, a psychological or physical trait, etc. For instance, the salient self-aspect, upon which the social identity of an ethnic group is based, could be the belief in a shared heritage (Simon 2004, cited in Jaspal 2009:17).

Claims that point to the existence of such an obligatory marker can be found throughout the sociolinguistic literature. In this first example, according to Dorais (2010), the 
obligatory markers for the Inuit of Canada appear to be 1) having Inuit parents and 2) practicing an Inuit way of life. It should be noted that their language, Inuktitut, is not endangered like the rest of the languages in this study. It functions as a provincial language, with $90 \%$ of the population speaking it. They have managed to maintain strong language vitality in a part of the world where many languages are fading fast.

The majority of the Inuit interviewed stated that language was extremely important for their sense of belonging to their Inuit identity. But when asked if it was imperative for group belonging, they said no, if one lost the Inuktitut language but either had Inuit parents and/or continued to live as an Inuit, that person would still be an Inuit, just a 'bad little Inuk'....In the eyes of the Inuit, one specific village of Inuit, the Mackenzie Inuvialuit, still remain fully Inuit, even if they have now lost their language (Dorais 2010:296-297; emphasis added).

The vast majority of the Mon in southeastern Myanmar do not speak their traditional language at all, having shifted to Burmese. But there is a remnant that does maintain the language. Watkins (2007) reports that for those who have shifted, 1) a body of speakers somewhere else, and 2) the memory of a language were the necessary markers of their Mon identity.

...the continued existence of $a$ partial body of speakers, or alternately simply the memory of a language having existed at one time in a community appears to be sufficient to satisfy the linguistic aspect of the maintenance of a separate ethnic identity (Watkins 2007:282)

In Sabah, Malaysia, most of the small Lotud communities are at an EGIDS 8a. Those in urban settings have completely lost their traditional L1. But they still proudly identify themselves as Lotud, even though they do not practice any of the ceremonies nor the way of life, nor (in the case of the urban migrants) live on the original land. According to their own leaders, it is their shared history that makes them Lotud (S. Pamanday, personal communication, 2015). ${ }^{12}$

The Batak of Sumatra, Indonesia, are a people whose language is strong in the home area, but weakened in the speech communities that have migrated to urban centers outside of northern Sumatra. Yet even in places where there is significant or even total language shift, the community continues to consider Batak as one of their main identities. C. Hanawalt (personal communication, 2015) suggests that membership in a clan plus shared ancestry appear to be the obligatory identity markers for the shifting Batak. Urban Batak migrants also claim Indonesian identity, thus maintaining multiple identities in their identity repertoire.

\footnotetext{
${ }^{12}$ The possibility that other options may not be open to the Lotud will be dealt with in the next section, when we consider the Language Ecology factors.
} 
Smalley (2010:200) and W. Hanna (personal communication, 2015) report that among the Tai Lue, there are many who have assimilated quite readily to Thai urban life and for all practical purposes become Thai (among those are some of my colleagues at Payap University in Chiang Mai). Then there are those who have remained in the rural villages. But in both cases, the language is almost completely gone, as are most of their traditional customs and way of life. Those who remain in the villages, however, are adamant that they are Tai Lue, and their obligatory markers are reported to be the white head cloth worn by the women and a shared ancestry. Those living in the city have apparently lost even these markers and claim Thai as their major identity.

In the Sepik area of northern Papua New Guinea, many groups are struggling to retain their heritage language. Most eventually succumb to the onslaught of Tok Pisin. But these shifting communities, like the Urimo, insist on maintaining their traditional identity even while losing their language. One of the Urimo leaders explained to me that they are Urimo because some of them still possess and live on their traditional land. As long as some of their people remain on their land, their identity is safe. If they lose their land, they lose their Urimo identity (Eberhard 2015b).

All the above vignettes offer a glimpse of what some communities and individuals (as well as their researchers) believe to be the obligatory markers that indicate a sense of belonging rooted in their past. A set of recurring traits emerged to form a general pool of characteristics from which endangered language communities choose those necessary or minimal symbols that best mark their ancestral identity. The possibilities for these obligatory markers thus seem to be constrained. In groups with higher oral language vitality, active markers such as 'language' and 'way of life' were the most prominent markers. The most common obligatory symbols in the highly endangered groups, where language was either spoken by only a handful or not at all, were passive markers: shared history, shared ancestry, clan membership, land ownership, and parental ethnicity.

The study of obligatory identity markers also shows that the markers themselves may change over time, while the identity stays intact. This was corroborated in a study of Maori identity in a number of Auckland communities (Starks, et al 2005). The study identified a large number of topics that were significant in the self-identification of Maori communities. As we might expect, the groups with the strongest Maori language vitality (Samoan and Tongan) rated 'way of life' and 'language' as the 2 highest topics related to identity. In the groups with weaker language use (Cook Island and Nieuan), passive markers were rated highest. This example of obligatory markers changing over time is based on the fact that each of these groups is part of the same general ethnic identity, Maori, and that they each presumably started with a similar if not identical set of active plus passive markers which they considered obligatory for that identity. The difference in the nature and number of the obligatory markers recently identified in the various Maori communities is best explained by the different rates of language and cultural loss experienced in each of the separate communities. 
Exceptional usage of obligatory identity markers can be found in communities which practice what I prefer to call 'delayed vernacular acquisition' (also referred to as 'late language acquisition'). ${ }^{13}$ Delayed vernacular acquisition occurs when the cultural norm is to learn a traditional language not as a child, but as an older youth or as a young adult. The traditional tongue is not passed on in the home, but learned outside the home. In practice, the resulting scenario is hard to distinguish from typical language shift and, in the long run, may simply be a longer drawn-out version of language shift, one that is not as linear as others. ${ }^{14}$ Little research is available on this particular language learning behavior, but in some of these cases at least, this practice appears to be primarily associated with the identity function of language, or language as an obligatory marker of identity.

The Forro community of São Tomé e Príncipe practice delayed vernacular acquisition. All the youth learn the national

\footnotetext{
13 'Late Language Acquisition' is perhaps a more common term to describe this practice, but it is unfortunately a label that has already been in use for some time in the applied linguistics field for children who learn their first language later than other children. In the cases here, however, we are talking about a cultural pattern of learning the vernacular as a second language later in life. Therefore, a term such as Delayed Vernacular Acquisition seems more appropriate (or even Language Learning Metathesis, where Yish is acquired before Xish).

14 Delayed Vernacular Acquisition is a remarkable example of the unpredictable nature of language use, the kind of thing that could have led Lewis (2000:97) to remark "While languages do die, I don't believe they very often do so in a straight line".
}

language, Portuguese, in the home. But a significant number of them also eventually learn São Tomé, the Portuguese-based creole that is their traditional language. This learning occurs among late teens or young adults as they begin to enter the adult world. Fluency is predictably an issue. The young people themselves admit that they are not as fluent as their elders. They cannot carry on extended conversations in São Tomé. It is used by the young adults mostly in greetings and light social banter, as well as in music lyrics. Rather than being employed for the communicative function of language, it seems to fulfill a symbolic function in the life of Forro society, marking one's identity as a Forro adult. Portuguese is the language of the home and of business, but São Tomé is the language of solidarity that links them to the adult generation of their people and their shared ancestry (Eberhard 2014b). It must be acknowledged, however, that the Forro community is also experiencing rapid language shift, as fewer and fewer youth are actually returning to learn the São Tomé creole. ${ }^{15}$

\section{Perceived Benefits of Xish}

Perceived benefits is a way of talking about the positive rewards of any particular social behavior from the perspective of those who practice it. The word 'perceived' indicates that the benefits may or may not be actual. What is important is that they are believed to

\footnotetext{
${ }^{15}$ Anderbeck (2013:8-9) reports the practice of delayed vernacular acquisition in Indonesia, in both Maluku and Papua. Bagamba describes the same behavior among the Lendu of DRC (Bagamba 2015:87). Whether its use in these locations is also motivated by an identity function is not yet clear.
} 
be so. The perceived benefits of using one language over another are considered by many to be the major cause of language shift. This basic insight was developed further into the 'Perceived Benefits Model' by Karan (2000). Here I will borrow Karan's term and apply it to identity, as I believe such value judgements of benefits are also the most powerful factors that affect the identity choices of members of minority groups. ${ }^{16}$

While the self-promoting benefits of Yish will be taken up in the next section, I will first apply this notion to the benefits of Xish identity. The primary motivation for hanging on to an Xish identity in a changing world has to do with the perception that there are continued internal benefits that such an identity can still provide for the Xish community. Preserving traditional land, treasured cultural practices and the artifacts of those practices are among the visible benefits. The continued use of traditional artistic and religious expressions can be viewed as aesthetic and spiritual benefits. Maintaining familiar social values, a familiar worldview, and useful bodies of knowledge are possible mental benefits. A clear sense of one's history and solidarity with one's ancestral or ethnic group provide crucial social or relational benefits. In regards to linguistic benefits, Fishman (2001:22) makes a powerful defense of the 'intangible' values of Xish, reminding us

${ }^{16}$ By applying Perceived Benefits analysis to identities (and not just languages), we are getting closer to the actual choices made by individuals, as identity choices are typically more conscious than language choices. Language shift is thus the result of identity choices, which are often driven by the perceived benefits of each identity. that its weakness is its strength. The very qualities of minority culture that are economically unimportant are those that are communally the most significant.

There are some minority communities who persist in hanging on to a traditional identity in difficult environments that are not favorable to Xish. In such cases, the above benefits of Xish identity do not seem 'reasonable' (at least to outsiders), particularly in the face of Yish benefits that are abundant and accessible and overpowering. It can even appear that such communities are making this choice 'against all odds'. Paulston (1994:16) describes this amazing quality of resilience (or even resistance) as one of "ethnic stubbornness". ${ }^{17}$ The Gavião de Rondonia in west-central Brazil (personal observation) come to mind as supreme examples of this fascinating ethnic trait. The Zoró and the Surui, both closely related to Gavião in all other apparent respects, exhibit no such feature and are shifting rapidly to a Brazilian identity. While the term would seem most applicable to groups who have maintained both their language and identity, it might also be applied (to a lesser degree) to groups who have lost their language but insist on preserving their traditional identity.

Inter-group conflicts, while part of the external environment of some communities, often serve to accentuate the internal benefits of Xish belonging. A heightened sense of solidarity arises around Xish identity in the face of conflict. This can be a

17 This is similar to the discussions of "change resistant cultures' in anthropology (See Oliver, 1965). 
powerful motivator. Particularly in armed conflict, when group boundaries are drawn in such stark relief, turning inward to strengthen Xish belonging helps to bring some sort of meaning to chaos, providing communal support to face an unknown and unstable future. Conflict thus typically strengthens minority languages by setting their speakers apart from their opponents and providing them with a cause that reenforces in-group solidarity and the notion of separateness. The benefit of such group allegiances, however, comes with an extremely high cost.

A final benefit of Xish is one that results from an external motivation, such as when Yish provides benefits for speaking Xish. Other benefits of Xish come from within the community in question (such as solidarity, sense of place, sense of history). But at times it may come from without. External benefits for being Xish usually include government benefits for being a member of a group with minority status. ${ }^{18}$ Xish identities whose sole motivation comes from the Yish world are at worst the least

18 The Cocama of Brazil have lost their traditional language and do not possess any identity markers that point them to their traditional culture. They are currently, however, asking non-profit organizations to help them revitalize their language. The motivation behind this request is reportedly linked to the receiving of government benefits (V. Soares, personal communication, 2015). It is quite common for communities in the Americas to lobby for indigenous rights based on traditional identity claims. When such Xish claims have no acts of identity to support them (passive or active), and when the only benefit of an Xish identity comes from the Yish world and not the Xish world, those claims are naturally suspect. convincing or at best the weakest type of group identity.

\section{Language ecology factors}

The second broad group of factors I will address that influence the identity of shifting language communities are those that come from the external context, or what has more recently been referred to as 'language ecology'. This term was first made popular by Haugen (1972:325). Two applications of the term are now common: a) broad sense the relationships between a language and its environment, linguistic and social; b) narrow sense - the responsibility to advocate for linguistic diversity on this planet, and to be involved in preserving that diversity at all costs (Edwards 2009:258). I will be using 'language ecology' here only in the first, broader sense, attempting to discover what the surrounding Yish culture can tell us about the identity choices of highly endangered language communities.

Besides community internal factors, there are also external ones which greatly affect identity allegiances. These ecology factors, however, are less prominent in the literature than many of the language internal factors (except perhaps for the 'benefits of Yish', which is often cited). The six factors below encode specific characteristics of Yish and its larger language ecology. They were chosen due to their saliency, based on my observations of minority communities both in the Americas and Asia. They are not intended to be comprehensive in any sense, but only to suggest a place to begin: 1) Perceived Benefits of Yish 2) Permeability of Yish 3) Social Distance 4) Mono/Plural Yish 5) Forced Identity 6) Conflict. 
It should also be noted that there is a crucial distinction between the first of these, the Perceived Benefit of Yish factor, and the rest. Perceived Benefits is an autonomous factor, implying freedom of choice on the part of the individuals in the Xish community. All of the rest are limiting factors, constraining the choices of Xish in various ways. I will present Perceived Benefits of Yish first, as that could be considered the default factor when all else is equal. After that, we will look at the more complex factors involved when this choice is constrained.

\section{Perceived Benefits of Yish}

According to Karan (2000:68-70), the benefits of Yish can be categorized under the following headings: communicative motivation, economic motivation, social motivation, and religious motivation. Improved education and better health services are also common benefits. When contact between Xish and Yish begins to change Xish lifestyles via the aforementioned factors, the standards and values of Xish may become harder to satisfy, while a new set of Yish-related values becomes more appealing and even more attainable (see Barth 1996:25). This cost/benefit negotiation is the driving force of language, culture, and identity shift. Joseph helps us to appreciate this process:

Most of those giving up their traditional language are, on the contrary, doing so as part of constructing an identity for themselves that is bound up with a conception of modernity (Joseph 2004:23).

The relative size gap between Xish and Yish cultures will influence the assessment of such benefits. Wherever there are language ecologies where Yish is not well developed, or is small in size and depth, the benefits gained from Xish communities shifting to a Yish identity may not be sufficient for the price that must be paid. In such cases, Xish communities may switch to Yish language but choose to remain Xish in identity. Many language groups in the Sepik of Papua New Guinea come to mind in this regard. The relatively modest benefits of becoming a part of Papua New Guinea national culture are not that far removed from the original benefits of Xish, and they certainly cannot compare to the benefits of becoming a part of, for example, Thai national culture, or Brazilian national culture. The latter have monolithic cultural footprints. The options available to minority groups in these different language ecologies influence (but don't determine) the identity choices they make. Thus we find that most Sepik groups are choosing to keep their identity, even after losing their language, while a significant percentage of minority groups in Thailand and Brazil are choosing to shift completely to a Yish identity.

In the 'Fluid Zone' of India, the large HindiUrdo-Panjabi area of the north central region, every 10 -year census shows that many ethnic and language groups are constantly changing their allegiance to language and identity due to the prevailing culture that will provide maximum benefit for each group at any given point in time (Khubchandani 1983:103-107). 
The Arbëresh communities of Italy, descendants of Albanian immigrants in the sixteenth century, have long maintained a preference for their distinct Albanian identity, even though not always maintaining their language of origin. However, in light of the bad press that new Albanian immigrants have received in Italy since the 1990's, the Arbëresh are now more likely to identify as Italian, an identity switch that has much to do with the perceived benefits of Yish over the perceived negative stereotype of Xish within the wider society (Joseph 2004:164-5, citing Perta 2003).

By including Perceived Benefits as a factor under both internal (Xish) and external (Yish) domains, I am recognizing that any discussion of benefits must take into account both worlds. Asking the question, "What is gained by preserving Xish?", must be balanced by the opposing question, "What is gained when we gain Yish?",

Due to the importance of a balanced approach to these critical issues, the responsibilities of field researchers become significant. One of the crucial tasks of those who journey alongside minority communities is to help build the awareness among local communities that both of the above questions are valid, and that if addressed early enough, there may be a way of reconciling them. Communities should not be forced to choose between the two, for many groups in fact choose them both. Stable, diglossic multilingualism supported by multiple identities is the most realistic option for preserving a minority identity and its accompanying language for use by future generations.
Whenever benefits are weighed in the balance, however, the possibility of complete language and identity shift to Yish is of course always present, a tendency that is more pronounced in some regions of the world than in others. Such a decision must be respected and supported if that is the true wish of the community. Community ownership in these decisions is fundamental, as decisions on these matters made by outsiders are rarely effective. Recent advances in language maintenance/language development theory, such as Resilience Linguistics (Bradley 2010), and the Sustainable Use Model (Lewis and Simons 2015a), are based on the understanding that any long-lasting development must come from within the community.

\section{Permeability of Yish}

Permeability is a way of measuring the ease with which members of an Xish language community are able to assimilate and become members of Yish. It is measured on a continuum from 'impermeable/low permeability', where there is little chance of assimilation, to 'permeable/high permeability', where assimilation is facilitated and expected. It is thus a measurement of social effort. Several subcomponents of permeability suggest themselves: 1) obligatory identity markers of Yish, which could require a change of one's religion, marriage preference, values, race, etc.; 2) 'doorways' for Xish within the Yish world, such as educational opportunities/ employment/ housing/ mixed marriages/ friends of Xish; 3) geographic location, or the relative distance between Xish and Yish and the effort it takes to cross it; and perhaps the most important, 
4) attitudes of Yish towards Xish. Note that each of these components (except perhaps for \#3) is firmly in the hands of Yish members, as they are the only ones who control both the definition of Yish identity and the requirements on those who wish to enter it. (While some may contend that urbanization, migration and diasporas are also components of permeability, I see them as the consequences of 'perceived permeability', the joint perceptions and hopes of Xish communities in regards to the possibility of being accepted into the Yish world. How long such displaced communities are able to stay or flourish in their new home will depend in large part on the factors outlined in this study)

A useful metaphor here is that of an identity wall, highlighting the relative 'difficulty' of assimilation instead of measuring the relative 'ease'. A high identity wall would correlate with low permeability, and a low identity wall with high permeability.

Other writers have proposed similar concepts; Wardhaugh (1987:14-15) with his 'openness' criteria, and Smalley (1993:330) with his 'bounded vs. centered' labels. Although Smalley focuses on how sharply defined a certain identity might be, in practice this has implications for the amount of effort it would take to break through such boundaries.

Ethnic labels can be bounded where the edges are clear-cut, or they are centered - which means the borders are fuzzy...If an ethnic category is strongly bounded, for someone to change ethnic identity may even be seen as traitorous (Smalley 1993:330-1).

Examples of highly permeable ecologies are Brazil and Thailand. ${ }^{19}$ Brazil's openness comes from a history of assimilating minorities who gradually have become a part of the fabric of society. Many indigenous peoples (such as the Tupinamba) are now extinct due to this assimilation process. ${ }^{20}$ Some current groups who have recently assimilated into the vast Brazilian world are the Torá (Anonby 47:2015), the Cocama (Lewis, Simons, and Fennig, 2015), and the Sabanê (personal observation).

Thai culture is for the most part highly permeable. Smalley (1993:346) describes the Thai as a culture where "ethnic categories are generally centered rather than bounded, so ethnic boundaries are not only porous, but also non-exclusive." Incorporation is the primary way of unifying the diversity of language and ethnicity in Thailand. Minority groups who have migrated to Thailand and succumbed to the strong Thai identity include the urban Tai Lue, the Thai Yai, the Mon, and the Northern Khmer. Even the powerful Chinese language and culture has bowed to the Thai world and most Chinese descendants in

19 "Enter Malay and go downstream" is a translation of a popular Indonesian idiom used in the past to express the ease with which minority groups could become a part of the larger society (K. Anderbeck, personal communication, 2015). How much this continues to be the case in Indonesia today is an issue open for debate.

${ }^{20}$ Of course, other groups became extinct due to warfare, genocide, and the many fatal epidemics unwittingly introduced into their communities by the 'branco'. 
Thailand are now more Thai than Chinese (Smalley 1993:3, 173). ${ }^{21}$

It is also possible for the same society to be highly permeable towards certain groups, and yet impermeable or less permeable towards others. This appears to be the situation of the Pattani Malay in Thailand. They have not assimilated into Thai culture as other groups have, and that seems to be due to the large differences between them and the Thai, differences based on history, language and religion (Smalley 1993:346). This point is closely related to the next language ecology factor, social distance.

\section{Social Distance}

This is a measurement of the perceived distance between Xish and Yish. How different are these groups? This can be measured on a continuum via the labels Proximate and Distant. The Social Distance scale can be applicable to characteristics of all sorts: Linguistic, Cultural, Ethnic, Religious, Ideology, Values, and Way of life among others.

The assumption I am making here is that social distance and permeability are often related. Specifically, I predict that in most language ecologies, Yish is more permeable to groups that are considered more 'proximate' and less permeable to groups

21 If ethnic groups want to incorporate and become Thai, they must register for the first time with the government. In the process they will be asked their religion. If they say they worship spirits, they are told that is not a religion and they are simply registered as Buddhists. The process is done. Barriers are eliminated. (Smalley1993:348). that are considered 'distant'. Perceiving others as similar to ourselves makes us more readily disposed to allow them to be part of our in-group.

The permeability of Yish can thus differ greatly depending on the Xish group under consideration and the 'social distance' involved. As mentioned above, the case of the Pattani Malay in Thailand (living on the border of Malaysia) and to a lesser degree the Hmong (originally from Laos) are considered to be bounded identities that are fundamentally distinct from a national feeling of Thai-ness. This leads to ways of behaving towards them that differ from the ways that Thais act towards the other ethnicities within their borders. The Tai ethnicities, on the other hand, are very close to the Thai linguistically and socially, and thus tend to meet less resistance when assimilating to Thai culture. The social distance scale is therefore significant in Thailand, a fact that is corroborated by Smalley (1993:238-254, 328-9), who has identified four stages of ethnic identity based on such social distinctions.

Social distance also appears to be a factor in other groups in my data, such as with the Domaaki in northern Pakistan, who assimilated to a Muslim regional identity in the north, but were already Muslims themselves (W. Lunsford, personal communication, 2015). In terms of religion, the Domaaki were proximate to the LWC. A contrasting example of social distance would be the case of the Calon, a large Roma group in Brazil, who have maintained a history of separateness from mainstream Brazil society. This has resulted in distrust on both sides, and the permeability of the Brazilian 
society often breaks down in this case. The Calon of the town of Guapó in the state of Goiás, for instance, have largely shifted to Portuguese, but have been limited in the amount of assimilation they have been able to achieve. Social distance appears to be one of their major challenges (Eberhard 2011).

\section{Mono vs. Plural Yish}

This characteristic of Yish describes the makeup of the larger language ecology, in particular, the composition of the nonminority community. If the majority community is itself split into various languages/ethnicities/religions, providing diversity at the higher levels of nationhood, then there is a plurality within Yish. If the non-minority community tends to belong to a single language/ethnicity/religion, then there is a monopoly of Yish.

Thailand and Brazil are once again useful for illustration. They are both language ecologies with a single monopolizing Yish community. Minority groups who want to adopt a larger identity within these countries have only one identity to choose from, Brazilian or Thai. The monolithic nature of these national identities, with a single language and/or a single religion, also contributes to their size, power, and influence over minority groups. Such monopolizing identities are hard for minorities to resist.

Some South East Asian countries, on the other hand, such as Malaysia and Indonesia, have developed a plurality within Yish. The existence of more than one large ethnic and/or religious bloc necessarily brings diversity at the country-wide level. Besides national citizenship, several country-wide identities are possible. Minorities, when observing the power relations of those above them in their language ecology, see a number of players on the national stage. This may or may not develop into more identity options for the minorities groups, but it certainly does temper the identity expectations at the higher levels. In such ecologies, it is not only permitted but in many cases expected that one would not only have a national identity, but also a separate ethnic or linguistic or religious identity. This openness to pluralism allows the minority identities to survive and flourish alongside much larger national ones. The diversity at the national level reflects in some sense the diversity at the minority level.

Such is not the case in monolithic, monopolizing ecologies. The expectation placed on minorities in places such as Brazil and Thailand is that all groups will learn the national language and culture, as expressed in one of its regional variants, eventually becoming monolingual and mono-cultural. The maintaining of diverse identities that go beyond regional differences is discouraged, and consequently minorities tend to lose their traditional identities with greater speed.

\section{Forced Identity}

An identity that is forced upon Xish groups by Yish authorities, or by the members of any LWC over them, is a forced identity. It may or may not involve conflict. This may take the form of a government limiting the number of ethnic groups it will recognize within its borders. It may also be used for situations where an LWC is attempting to 
control the allegiance of smaller groups by force. The example of the Ngai/Nung or 'Vietnamese boat people' is one of forced identity, where an outsider assigns the identities of insiders.

The whole process of shifting from north to south Vietnam, from Vietnam to China and then to Hong Kong was in a way a continual experience of 'negative identity'. As one woman from another group of Ngai/Nung put it to me recently: 'In Vietnam we were Chinese, in China we were Vietnamese' (Hutton 1998:127).

Forced identity may at times be connected to the permeability factor. If Yish does not wish Xish to belong to their in-group (low permeability), then it may force Xish to take another label (forced identity). Examples of forced identity + low permeability are not often reported but there is reason to believe it is common in many parts of South East Asia. Edwards (2009:162) observed the following incident in Singapore, which only allows for 4 official languages: Tamil, Malay, Mandarin, and English. All citizens must be bureaucratically assigned to one of these official languages as well as to the ethnic group it represents. If the category does not fit, there is no recourse. This means that Singaporean Indians whose mother tongue is Malayalam are put in the Tamil camp even if they don't speak it. Chinese Hokkien speakers are put in the Mandarin camp. A Chinese Malay civil servant whose first language was Malay was put in the Chinese camp. He asked to take an examination in Malay but was forced to take it in Chinese. The reason given was that he was an ethnic Chinese, and that because of his ethnicity, he must be categorized in the Mandarin camp.

\section{Conclusion}

We have seen that communities whose languages are endangered may still have options open to them in regards to their group identity. The various factors affecting the identity choices of minority groups in advanced levels of language shift can be categorized as those originating from within the community and those originating from the broader language ecology. The internal factors include Obligatory Markers and Perceived Benefits of Xish. The former are the minimal required acts of identity chosen by specific communities, and these may be either active or passive. Language ecology factors that affect identity may be of the autonomous type, allowing for freedom of choice, or the limiting type, constraining such choice. Perceived Benefits of Yish is a language ecology factor of the autonomous type. The rest are of the limiting type, which includes Permeability of Yish, Social Distance, Mono/Plural Yish, and Forced Identity. These various groupings of factors provide a beginning towards understanding what lies behind the diverse identity choices that minority communities make when faced with advanced language shift. This understanding can then help those involved in language development to be more sensitive to the pressures on identity felt by minority communities, as well as to respect the need for community autonomy in making any decisions relating to their future identity and language use. Language is always about identity, but identity is not always about language. 


\section{References}

Anderbeck, Karl. 2013. Portraits of Indonesian Language Vitality. Paper presented at Pacific Linguistics ICAL 2012, Language Documentation and cultural practices in the Austronesian world, Malaysia.

Anderson, Benedict R. 1991. Imagined communities: reflections on the origin and spread of nationalism. London: Verso.

Anonby, Stan. 1999. Reversing Language Shift: Can Kwak'wala be Revived. In Revitalizing Indigenous Languages, edited by Jon Reyhner, Gina Cantoni, Robert N. St. Clair, and Evangeline Parsons Yazzie, pp. 33-52. Flagstaff, Arizona: Northern Arizona University Press.

---. 2015. The Extended Graded Intergenerational Disruption Scale Applied in Brazil. In Ecological Perspectives on Language Endangerment: Applying the Sustainable Use Model for Language Development, edited by M. Paul Lewis and Gary F. Simons, pp. 35-56. Online Publishing: LeanPub.

Bagamba B. Araali and Douglas W. Boone. 2015. Challenges to Applying the EGIDS in Northeastern Democratic Republic of Congo. In Ecological Perspectives on Language Endangerment: Applying the Sustainable Use Model for Language Development, edited by M. Paul Lewis and Gary F. Simons, pp.69-103. Online Publishing: LeanPub.
Barth, Fredrik. 1969. Ethnic Groups and Boundaries. Boston: Little, Brown, and Company.

Bourdieu, Pierre. 1977. Outline of a Theory of Practice. Cambridge: Cambridge University Press.

Bradley, David. 2010. Language Endangerment and Resilience Linguistics: Case Studies of Gong and Lisu. Anthropological Linguistics 52.2: 123-140.

Dauenhauer, Nora and Richar Dauenhauer. 1998. Technical, emotional and ideological issues in reversing language shift: examples from Southeast Alaska. In Endangered Languages, edited by Lenore Grenoble and Lindsay Whaley, pp. 57-98. Cambridge: Cambridge University Press.

Dorais, Louis-Jacques. 2010. The Language of the Inuit: Syntax, semantics and society in the Arctic. Montreal: McGillQueen's University Press.

Dorian, Nancy C. 1999. Linguistic and Ethnographic Fieldwork. In Handbook of Ethnic Identity, edited by Joshua Fishman, 25-41. Oxford: Oxford University Press.

Eberhard. David. 2011. Pesquisa sociolinguística preliminar dos Calon brasileiros. S.I.L. archives.

---. 2013. Report on SUM workshop, Brasília, Brazil. S.I.L. archives. 
MANUSYA: Journal of Humanities Regular 21.2, 2018

---. 2014a. Report on SUM workshop, Kota Kinabalu, Malaysia. S.I.L. archives.

---. 2014b. Report on SUM workshop, São Tomé e Príncipe, S.I.L. archives.

---. 2015a. Report on SUM workshop, Kuching, Malaysia. S.I.L. archives.

---. 2015b. Report on SUM workshop, Sepik and Highlands, PNG. S.I.L. archives.

Edwards, John. 2009. Language and Identity. Cambridge: Cambridge University Press.

Fischer, Christopher J., 2010. Alsace to the Alsatians? Visions and Divisions of Alsatian Regionalism, 1870-1939. New York: Berghahn Books.

Fishman, Joshua. A. 1991. Reversing Language Shift: Theoretical and Empirical Foundations of Assistance to Threatened Languages. Clevedon: Multilingual Matters.

---. 2001. Why is it so hard to save a threatened language? In Can threatened languages be saved, edited by Joshua Fishman, 1-22. Clevedon, UK:

Multilingual Matters, Ltd.

Goffman E. 1959. The Presentation of Self in Everyday Life. New York: Doubleday

Grenoble, Lenore and Lindsay Whaley. 1998. Endangered Languages. Cambridge: Cambridge University Press.

Grin, F. et al. 2003. Language Policy Evaluation and the European Charter for
Regional or Minority Languages. Basingstoke: Palgrave Macmillan.

Harré, R. and L. Van Langenhove. 1999. Positioning Theory: Moral contexts of intentional action. Oxford: Blackwell.

Haugen, E. 1972. The Ecology of Language. Stanford University Press, Stanford, CA.

Hutton, Christopher. 1988. From premodern to modern: ethnic classification by language and the case of the Ngai/ Nung of Vietnam. Language \& Communication 18: 125-132.

Jaspal, Rusi. 2009. Language and Social Identity. Psych-Talk, September 2009 $<$ https:/www.academia.edu/200226/ Language_and_social_identity_a_psycho social_approach>.

Joseph, John. 2004. Language and Identity: National, Ethnic, Religious. Basingstoke: Palgrave Macmillan.

Karan, Mark E. 2000. Motivations: Language Vitality Assessments using the Perceived Benefit model of Language Shift. In Assessing Ethnolinguistic Vitality: Theory and Practice, edited by Paul Lewis and Gloria Kendell, pp. 6578.

---. 2011. Understanding and forecasting ethnolinguistic vitality. Journal of Multilingual and Multicultural Development 32: 137-149.

Keyes, Charles. 1992. Who are the Lue? Revisited Ethnic Identity in Laos, Thailand, and China. A Working Paper 
from The Center For International

Studies. MIT Cambridge, Massachusetts.

Khubchandani, Lachman. 1983. Plural

Languages and Cultures:

communication, identity, and sociopolitical change in contemporary

India. Honolulu, University of Hawaii

Press.

Kitingan, Joseph Pairin. 1995. Kadazan-

Dusun Malay English dictionary. Kota

Kinabalu, Sabah: Kadazan-Dusun

Cultural Association.

Le Page, Robert B., \& Andree TabouretKeller. 1985. Acts of Identity: Creolebased Approaches to Language and Ethnicity. Cambridge: Cambridge University Press.

Lewis, Paul. 2000. Power and Solidarity as Metrics in Language Survey Data Analysis, p79-99. In Assessing Ethnolinguistic Vitality, eited by Paul Lewis and Gloria Kindell. Dallas: SIL.

---. 2010. The Sustainable Use Model. Payap University colloquium.

Lewis, M. Paul and Gary F. Simons. 2010. Assessing Endangerment: Expanding Fishman's GIDS. Revue Roumaine de Linguistique 55.2: 103-120.

---. 2015a. Sustaining Language Use: Perspectives on Community-Based Language Development. Online publishing: LeanPub.

---. 2015b. Ecological Perspectives on Language Endangerment: Applying the
Sustainable Use Model for Language

Development. Online

Publishing:LeanPub.

Lewis, M. Paul, Gary F. Simons, and Charles D. Fennig (eds.). 2015.

Ethnologue: Languages of the World, Eighteenth edition. Dallas, Texas: SIL International.

McCall, GJ and JL Simmons. 1978.

Identities and Interactions: An

Examination of Human Associations in Everyday Life. New York: Free Press.

Moerman, Michael.1965. Ethnic Identification in a Complex Civilization: Who Are the Lue?. American Anthropologist 67.5: 1215-1230.

Nettle, D., \& S. Romaine. 2002. Vanishing Voices: The Extinction of the World's Languages. Oxford: Oxford University Press.

Oliver, S. C. 1965. Individuality, Freedom of Choice, and Cultural Flexibility of the Kamba. American Anthropologist 67: 421-428.

Paultson, Christina. 1994. Linguistic minorities in multilingual settings: implications for language policies. Amsterdam: John Benjamins.

Romaine, S. 2008. Linguistic diversity, sustainability, and the future of the past. In Sustaining Linguistic Diversity: Endangered and Minority Languages and Language Varieties, edited by K. King, N. Schilling-Estes, L. Fogle \& Lou, J., 
pp. 7-22. Washington, DC: Georgetown University Press.

Schmidt, Ulrike. 2008. Language Loss and the Ethnic Identity of Minorities. ECMI Issue Brief \#18, November 2008, Flensburg : European Centre For Minority Issues (ECMI).

Simon, B. 2004. Identity in modern society: A social psychological perspective. Oxford: Blackwell

Smalley, William. 1993. Linguistic Diversity and National Unity: Language Ecology in Thailand. Chicago: University of Chicago.

Solomon, Robert C. 2005. "Subjectivity". In Oxford Companion to Philosophy, edited by Ted Honderich, pp. 900. Oxford: Oxford University.

Starks, Donna, Melenaite Taumoefolau, Allan Bell and Karen Davis. 2005. Language as a Marker of Ethnic Identity in New Zealand's Pasifika Communities. In ISB4: Proceedings of the 4th International Symposium on Bilingualism, edited by James Cohen, Kara T. McAlister, Kellie Rolstad, and Jeff MacSwan, pp. 2189-2196. Somerville, MA: Cascadilla Press.

Tabouret-Keller, Andrée.1998. Language and Identity. In The Handbook of Sociolinguistics, edited by Coulmas, Florian, pp. 315-326. Oxford: Blackwell Publishing.

Tajfel, H. and Turner, J. C. 1986. The social identity theory of inter-group behavior. In
Psychology of Intergroup Relations, edited by S.Worchel and L. W. Austin, pp. 7-24. Chicago: Nelson-Hall.

UNESCO. 2011. UNESCO's Language Vitality and Endangerment Methodological Guideline: Review of Application and Feedback since 2003. May 30- June 1, 2011

$<$ http://www.unesco.org/new/fileadmin/ MULTIMEDIA/HQ/CI/CI/pdf/unesco_ language_vitaly_and_endangerment methodological_guideline.pdf.>.

Watkins Justin. 2007. Burma/Myanmar. In Language and national identity in Asia, edited by Andrew Simpson, pp. 263-287. Oxford: Oxford University.

\section{Appendix - Language data sources}

Batak - C. Hanawalt, personal communication, 2015;

Calon - Eberhard 2011;

Domaaki - W. Lunsford, personal communication, 2015;

Fulniô - Anonby 2015:44;

Irish - Edwards, 2009:25;

Kajaman (Longhouse) - Eberhard 2015b;

Lotud - Eberhard 2014a; Maori (Cook Islands) - Starks, et al 2005:2192;

Marori - Anderbeck 2013:2;

Mon - Watkins 2007:281; 
Smalley 1993:222;

Pame - S. Berthiuame, personal communication, 2015;

Sabanê - Eberhard personal observation;

São Tomé - Eberhard 2014b;

Tai Lue (rural) - Keyes 1976/1981;

Tai Lue (urban) - W. Hanna, personal communication, 2015/ Smalley, 1993:200;

Terena - H. Terena, personal communication, 2015;

Tlingit - Dauenhauer and Dauenhauer 1998:73;

Torá - Anonby 2015:47;

Urimo - Eberhard 2015b. 